\title{
Human Endothelial Progenitor Cells
}

\author{
Mervin C. Yoder \\ Department of Pediatrics, Herman B Wells Center for Pediatrics Research, Indiana University \\ School of Medicine, Indianapolis, Indiana 46142 \\ Correspondence: myoder@iupui.edu
}

Human endothelial progenitor cells (EPCs) have been generally defined as circulating cells that express a variety of cell surface markers similar to those expressed by vascular endothelial cells, adhere to endothelium at sites of hypoxia/ischemia, and participate in new vessel formation. Although no specific marker for an EPC has been identified, a panel of markers has been consistently used as a surrogate marker for cells displaying the vascular regenerative properties of the putative EPC. However, it is now clear that a host of hematopoietic and vascular endothelial subsets display the same panel of antigens and can only be discriminated by an extensive gene expression analysis or use of a variety of functional assays that are not often applied. This article reviews our current understanding of the many cell subsets that constitute the term EPC and provides a concluding perspective as to the various roles played by these circulating or resident cells in vessel repair and regeneration in human subjects.

$T_{\text {in }}^{\text {he }}$ he importance of the systemic vasculature in mediating optimal delivery, exchange, and removal of gases, nutrients, and regulatory cells and molecules to the tissues and organs of a mature subject has long been appreciated (Aird 2007). More recently, interest in the role of the vasculature in promoting organogenesis during development, stem cell homeostasis, rescue of injured tissues following an ischemic/hypoxic challenge, and the growth and spread of cancer cells within the body has grown exponentially as investigators have probed new approaches for cellular therapies in all areas of human health and disease. Concomitant with these interests in translational research, investigators have become enthralled with the discovery of novel adult stem/progenitor cell populations that may be involved in the development, repair, or regeneration of the systemic vasculature. The first reported existence of a bone marrowderived circulating progenitor for the endothelial lineage called the endothelial progenitor cell (EPC) in 1997 (Asahara et al. 1997) initiated a robust area of investigation in experimental animals and human subjects with nearly 9500 papers cited in the PubMed database as of January 1, 2011 using the search term "endothelial progenitor cell."

In contrast to the vast number of papers elucidating roles of putative bone marrow-derived EPC in cancer (Lyden et al. 2001; Mancuso et al. 2001, 2006, 2009; Bertolini et al. 2006; Shaked et al. 2006; Nolan et al. 2007; Gao et al. 2008; Seandel et al. 2008; Gao and Mittal 2009), cardiovascular disorders (Eizawa et al. 2004; Schmidt-Lucke et al. 2005; Werner et al. 2005;

Editors: Michael Klagsbrun and Patricia D'Amore

Additional Perspectives on Angiogenesis available at www.perspectivesinmedicine.org

Copyright (C) 2012 Cold Spring Harbor Laboratory Press; all rights reserved; doi: 10.1101/cshperspect.a006692

Cite this article as Cold Spring Harb Perspect Med 2012;2:a006692 
M.C. Yoder

Fadini et al. 2006a,b; Kunz et al. 2006; Hughes et al. 2007), and diabetes (Tepper et al. 2002; Eizawa et al. 2004; Loomans et al. 2004; Fadini et al. 2006b, 2007), little focus has been placed on fully understanding how these cells may differ in their roles, behavior, or function compared to the rare circulating endothelial cells that may also be involved in many of these same disorders. This overview will attempt to summarize our current understanding of the various cell subsets that circulate in the bloodstream and are all referred to using the same EPC terminology. Given that no specific cell surface marker or unique gene expression pattern has been identified to unambiguously mark an EPC in mouse or man, we will identify those tools currently used to identify the putative EPC phenotype and will stress the differences in cell function displayed by the various "EPC" subsets.

\section{BLOOD VESSEL FORMATION, REPAIR, AND REMODELING ARE REGULATED BY DIFFERING MECHANISMS}

Blood vessel formation in the embryo has been examined in numerous vertebrate model systems. In the mouse, angioblast precursors derived from posterior primitive streak-derived mesoderm cells emerge on embryonic day (E)7.5 to initiate the process of vasculogenesis (Risau and Flamme 1995; Sabin 2002). The angioblasts migrate into the extraembryonic yolk sac to form a primitive capillary plexus. In time other angioblasts from later primitive streak-derived mesoderm populations migrate into and colonize the embryo proper and complete the first systemic vascular capillary bed by E8.25. The first blood cells to emerge in the developing mouse are the primitive erythroid progenitor (EryP) cells that independently migrate into the yolk sac (Fig. 1) and segregate into a circumferential extravascular band of erythroid cells (Ferkowicz et al. 2003). Near the time of onset of cardiac contractions that promulgate the first evidence of systemic blood circulation, the extraembryonic blood band is circumscribed by adjacent endothelial cells and the first blood-filled capillary structures called blood islands are formed. Over the next $36 \mathrm{~h}$, the blood islands are remodeled via intussuceptive angiogenesis and arteriogenesis into the various arterial, venous, and capillary beds of the mature yolk sac. Some of these endothelial cells display the capacity to form definitive hematopoietic progenitor cells that display multipotential hematopoietic lineage potential. Of interest, the systemic vascular bed is not completely filled with circulating blood cells until nearly E10.5. Thus, while arising nearly simultaneously from mesoderm, the EryP, definitive progenitor cells, and angioblasts do not appear to be derived from a common precursor, the hemangioblast, as often cited (reviewed in Ferkowicz and Yoder 2005; Ueno and Weissman 2010). Recent studies suggesting that the hemangioblast gives rise to hemogenic endothelial cells (which subsequently form the definitive hematopoietic lineages) only partially explains the origins of the EryP and fails to explain the origin of the earliest primitive capillary plexus (in which no blood cells emerge). Thus, in the earliest stages of blood vessel formation, hematopoiesis and vasculogenesis are independently executed developmental events that arise from mesoderm precursors. The fact that these lineages arise at nearly the same time and place in the developing embryo no longer infers that they arise from a common precursor.

Once the capillary plexus is formed, further expansion of blood vessel growth occurs via angiogenesis, as well as vasculogenesis (Risau and Flamme 1995). Angiogenesis is the formation of new vessels from endothelial cells representing already existing vascular structures in the embryo. In some cases, new vessels form from sprouting capillary endothelium within the primitive capillary plexus. In other cases, the sprouting endothelial cells arise from vascular structures remodeled into arterial or venous appearing structures. It is apparent that the metabolic demands of the tissue participate in the remodeling of the primary capillary plexus to define the final vascular bed density. As reviewed elsewhere (Davis and Senger 2008; Iruela-Arispe and Davis 2009; Eilken and Adams 2010; Pitulescu and Adams 2010), 


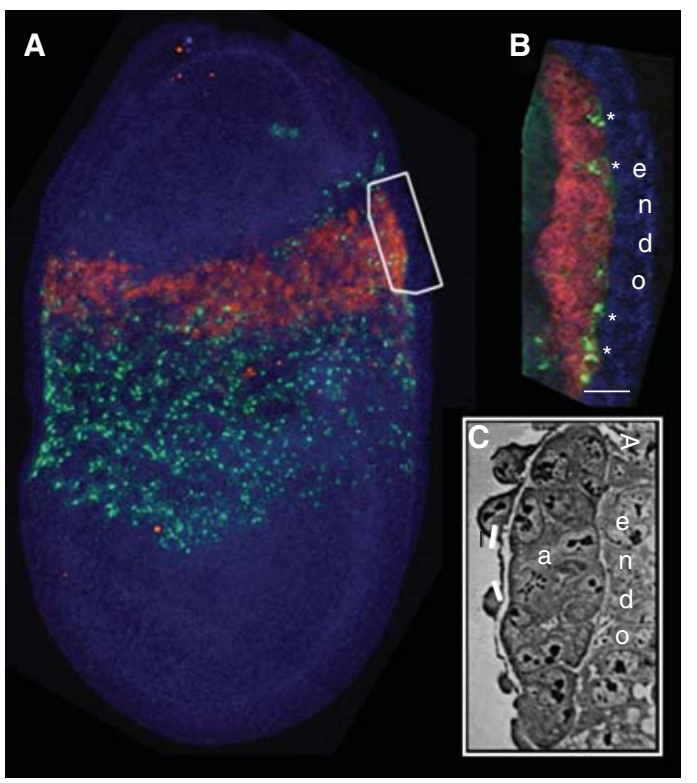

Figure 1. A late neural plate stage embryo. (A) Late neural plate stage mouse embryo with maturing Flk- $1^{+}$vascular plexus (green) and distinct band of $\mathrm{CD} 41^{+}$primitive erythroid progenitor cells in the proximal yolk sac (red). Note the paucity of angioblasts (green) in the blood band region. (B) Higher-magnification cross section of the blood band. The Flk- $1^{+}$angioblasts (green cells identified by asterisks) are located between the primitive erythroid progenitor cells and the yolk sac visceral endoderm (blue cells indicated by endo) cells. $(C)$ Blood island image depicting an angioblastic cord (a) from the same stage embryo as in panels $A$ and $B$. Note the similarity of the cross section of the tissue in panel $B$ to the panel $C$. The primary difference is the evidence that the cells highlighted in red in panel $B$ are now known to be primitive erythroid cells and not mesoderm (angioblastic) cords as once thought $(C)$. (Figure adapted from Ferkowitz 2005; reprinted, with permission, from Elsevier (C) 2005.)

genetic programmatic features and hemodynamic stressors play important roles in the capillary plexus remodeling into arteries and veins. Some evidence supports the role of hemodynamic stress on endothelial cells as an important component that promotes hematopoietic progenitor cell emergence from hemogenic endothelium (Adamo et al. 2009). A host of molecular mechanisms are now well understood in the regulation of the endothelial sprouting that represents a key event for new vessel formation. Subsequent steps of matrix degradation, endothelial sprouting, endothelial cell migration, cell-to-cell interactions with adjacent endothelial cells, cytoplasmic vacuolation and lumenization, basement membrane synthesis, and inosculation with preexisting vessels to access systemic blood flow are subsequent steps in vessel formation (Iruela-Arispe and Davis 2009).
In certain circumstances, a denudation injury to the vascular endothelium can occur that may not perturb the underlying endothelial basement membrane but requires rapid cellular recruitment to cover the otherwise thrombogenic exposed basement membrane (Schwartz et al. 1980). For example, traumatic injury may compromise the health of the vascular intima without harming the rest of the vessel components. Localized areas of inflammation may compromise vascular endothelial health and survival, leading to enhanced endothelial turnover (Schwartz et al. 1981). Apparently, the first events that occur to repair denudation of the endothelium (in experimental models) include deposition of platelets to the exposed basement membrane, increased migratory behavior of the endothelium adjacent to the injury, and endothelial cell spreading into the injury site (Schwartz et al. 1975; Malczak and 
M.C. Yoder

Buck 1977; Manderson and Campbell 1986). For small injuries, endothelial migration and spreading can result in closure of the previously denuded area within a day. Subsequently, endothelial cell proliferation ( first within more distal cells but later even in those cells that had migrated over the injury site) ensues, often leading to an eventual increased cellular density over the primary injury site that is several times that of the original cell density. Thus, the major cell type involved in the resolution of a denudation injury and return of the endothelial monolayer to the original topography and function of that vessel is the endogenous adjacent endothelium resident within the vessel (Schwartz and Benditt 1976). Whether similar events occur to replace senescent endothelial cells, without ever exposing the underlying basement membrane for circulating blood cell attachment, is unclear. Prior studies in rodent and pig models of normal vascular growth or induced vascular injury suggest that proliferating clusters of endothelial cells are apparent in vessels without signs of vascular denudation, providing some support for the presence of endogenous endothelial replacement (Wright 1968, 1971, 1972; Florentin et al. 1969; Caplan and Schwartz 1973; Schwartz and Benditt 1976, 1977; Schwartz et al. 1980, 1981; Prescott and Muller 1983; Taylor and Lewis 1986).

If large areas of endothelium are removed and/or there is damage to the underlying basement membrane or an artificial vascular grafting is interposed within vessels, greater influx of circulating cells ensues as a first response to injury. In this instance, a host of circulating hematopoietic cells along with platelets readily attach to these areas of damage or to the grafted artificial material (Rafii et al. 1995). In some instances, these deposited blood cells from the circulating blood are soon replaced by migrating and spreading endogenous endothelium. In other instances, colonies of replicating endothelial cells grow on the exposed area but fail to completely repopulate the monolayer and with time these areas of exposed basement membrane develop a fibrous and nonthrombogenic covering (Berger et al. 1972; Herring et al. 1984; Clowes et al. 1985, 1986; Zilla et al. 1994,
2007). Thus, the extent and type of vascular intima repair or regeneration is perhaps dependent on the extent and type of injury or implant and perhaps the age of the host. It is also well known that there are species-specific factors that may differentially regulate reendothelialization of denuded vessels (Berger et al. 1972; Herring et al. 1984; Clowes et al. 1985).

Finally, tumor cell growth, expansion, and metastasis depends on the ability of the tumor cells to secrete a variety of molecules that coopt circulating and resident proangiogenic cells in the tumor microenvironment to promote angiogenesis (Mancuso and Bertolini 2010). Tumor angiogenesis is perhaps the most complicated context within which to understand all of the cellular elements contributing to the tumor vascular growth. Not only do tumor cells recruit local and resident cells that include tumor-associated macrophages, tissue macrophages, mast cells, monocytes, neutrophils, and platelets that promote neoangiogenesis with sprouting of nearby vascular endothelium into the tumor, but in some cases, tumor cells may become vessel-mimicking or actual vessel-forming cells (Hirschi et al. 2008; RicciVitiani et al. 2010; Wang et al. 2010). It is within this complex heterogenous tumor microenvironment that some investigators have observed recruitment of circulating putative EPCs that play a role in enhancing tumor growth and metastasis. Defining those cells that represent EPCs and truly become long-term endothelial cells that comprise the tumor vessels versus those that enhance the vessel-forming properties of recruited endothelial cells but do not directly become endothelial cells is an important issue in developing the most powerful and effective drugs to inhibit all of the cells involved in the most effective tumor therapy (Bautch 2010).

\section{METHODS TO DEFINE HUMAN EPCs}

In the human system, putative EPCs have been identified using three general approaches. One of the first and perhaps the simplest method involves collecting low density mononuclear cells (MNCs) from human peripheral blood 
or cord blood and plating the MNCs in dishes coated with fibronectin in a commercial cell culture medium containing endothelial growth factors and fetal calf serum (Ito et al. 1999; Hill et al. 2003). After 4-5 days in culture, the nonattached cells are removed and the adherent cells examined for the ability to bind acetylated low-density lipoprotein (AcLDL) and Ulex europaeus agglutinin 1 (a plant lectin). Thus, EPCs, as defined in this assay, are characterized by their morphologic appearance, adhesion to fibronectin, cell surface protein expression, AcLDL uptake, and lectin binding. Although this is a simple method for isolating an adherent cell population, it may be flawed by the lack of specificity of the cells obtained. For example, blood platelets are known to contaminate most MNC preparations and the presence of platelets in this culture milieu can result in nondiscriminate transfer of platelet plasma membrane proteins to any adherent cells also attached to the culture matrix (including certain proteins thought to be endothelial specific) (Prokopi et al. 2009). Numerous blood cells (stem, progenitor, or committed mature lineages) express the integrin receptors for fibronectin and attach to plates coated with this molecule. In fact, monocytes are known to be highly enriched from peripheral blood MNCs when plated on fibronectin-coated dishes, and adherent monocytes cultured in media containing endothelial growth factors are known to express a variety of proteins typically thought to be reserved for endothelial cells (von Willebrand factor, endothelial nitric oxide synthase, CD31, CD144, and vascular endothelial growth factor 2 receptor $[\mathrm{KDR}]$ ) (Hassan et al. 1986; Schmeisser et al. 2001, 2003). Recent proteomic and mRNA profiling analyses have indicated that human peripheral blood MNCs cultured as adherent cells on fibronectin-coated dishes in culture medium with added endothelial growth factors display a gene expression pattern that highly resembles hematopoietic (particularly cultured myeloid and T lymphoid cells) but not human endothelial cells (Medina et al. 2010). Thus, this very straightforward method of adherent MNC growth in vitro does not promote the unique emergence of an
EPC. Thus, given the ambiguity of this isolation method, one cannot recommend using this approach for EPC isolation or enumeration. As we will discuss later, this does not mean that the hematopoietic cells isolated via this technique and cultured under these conditions do not display proangiogenic activity; in fact, one can readily obtain proangiogenic hematopoietic cells using this approach that participate in ischemic hindlimb blood flow restoration in mice and even demonstrated some ability to improve cardiac outcomes in human subjects with acute myocardial infarction (Tongers et al. 2010). We simply point out that some of the lack of clarity in the field may relate to the use of the term EPC for cells isolated using this procedure when, in fact, in nearly all cases, proangiogenic hematopoietic cells (of various lineages) are selected and these cells though promoting vessel repair but do not become long-lived endothelial lined blood vessels.

A second method of human EPC identification has relied on identification of a particular pattern of cell surface antigen expression on the cells. As noted above, there are no unique or specific protein markers that can be used to prospectively isolate an EPC (reviewed in Hirschi et al. 2008). The first description of a human EPC by Asahara et al. (1997) was dependent on the selection of circulating cells with certain cell surface markers that might be expressed by both hematopoietic and endothelial cells so as to search for a putative circulating angioblast precursor. Although this rationale was based on the long-held recognition for the close temporal and spatial emergence of blood and endothelial cells during embryogenesis, the most current understanding of blood cell and angioblast development indicates that these lineages may not be derived from a common precursor. Indeed, evidence supports the origin of hematopoietic stem and progenitor cells from hemogenic endothelium but not endothelial cells from blood cells (Yoder et al. 2007; Zovein et al. 2008; Chen et al. 2009). Asahara et al. (1997) isolated human peripheral blood CD34-expressing cells $(15.7 \%$ enriched for $\mathrm{CD} 34^{+}$-expression) and reported that cell adhesion to fibronectin-coated dishes was 
M.C. Yoder

significantly greater than to type 1 collagen coated dishes and that the CD34 enriched cells displayed a spindle-shaped morphology in this culture system. Of interest, the putative CD34 ${ }^{+}$EPCs when cocultured with CD $34^{-}$ MNCs on the fibronectin-coated dishes formed clusters of round cells centrally and sprouts of spindle-shaped cells at the periphery. The authors pointed out that these clustered structures were reminiscent of the blood island-like clusters normally found in the developing embryonic yolk sac. The adherent putative EPCs expressed a variety of cell surface proteins typically expressed by human umbilical vein endothelial cells, and expression of these markers increased over time in vitro. Further studies provided evidence that vascular endothelial growth factor receptor 2 (Flk- $\left.1^{+}\right)$ expressing putative EPCs (enriched to 20\% Flk- $1^{+}$) homed to areas of neovascularization when injected into nude mice with induced hindlimb ischemia with some evidence for improved microvascular density after infusion. Thus, in one article, Asahara et al. (1997) brought forth concepts of circulating EPCs, in vitro observations of EPC behavior, in vivo migration of putative EPCs to sites of vascular injury, and the paradigm of postnatal vasculogenesis whereby circulating EPCs could be infused into an animal with subsequent contribution to tissue microvasculature. These were and are important observations that have stimulated many investigators to understand the biology of these cells, attempt to characterize their concentration in health and disease, and isolate and infuse these cells into patients with acute or chronic ischemic diseases. However, potential limitations of this paper included the lack of sufficient cellular enrichment to constitute a purified cell population, lack of clonal analytical studies, failure to provide any functional exclusionary evidence as to whether any of the CD34 ${ }^{+}$or Flk- ${ }^{+}$EPCs possessed hematopoietic potential (given the fact that many of the cultured CD34 ${ }^{+}$cells displayed CD45), and lack of high cellular resolution evidence that the infused cells directly formed the new blood vessels in the tissues of the mice with induced vascular injury. Nonetheless, the use of CD34 and
Flk-1 (KDR in human subjects) as markers for the putative EPCs were instituted with this publication and have continued to be used as surrogate markers for the presence of a circulating cell with vascular reparative properties or in the isolation of this putative precursor.

The choice of CD34 as a potential marker of the circulating angioblast was not surprising as it is known to be expressed on endothelial cells and is a marker used to isolate human hematopoietic stem and progenitor cells for clinical stem cell transplantation. But, CD34 is a widely expressed molecule on some mesenchymal, epithelial, and even cancer stem cell populations (Hirschi et al. 2008). Thus, use of CD34 as an individual EPC marker is inadequate and would certainly require the search for additional potentially unique markers to discriminate all these different cellular lineages from the putative EPCs. KDR (human) or Flk-1 (mouse), a receptor for vascular endothelial growth factor, is also widely expressed on blood, endothelial, and cardiac cells and thus fails to be a helpful discriminator among those cells expressing CD34. Rationalizing that EPCs may share some cell surface antigen expression patterns with hematopoietic stem or progenitor cells, Peichev et al. (2000) chose to separate peripheral blood cells by expression patterns for CD34, KDR, and CD133. CD133 (AC133, prominin-1) is a 5-transmembrane domain cell surface glycoprotein that localizes to membrane protrusions on numerous epithelial, hematopoietic, and various cancer stem cells. CD34 and CD133 were known to be highly expressed on hematopoietic stem cells and are down-regulated during hematopoietic cell differentiation. Given this expression pattern in hematopoiesis, Peichev et al. (2000) rationalized that any endothelial cells coexpressing these molecules may represent a more immature progenitor population than cells expressing either antigen alone. Furthermore, because KDR was known to be expressed by embryonic angioblasts, Peichev et al. (2000) hypothesized that this antigen may be coexpressed on subsets of $\mathrm{CD}_{133}{ }^{+}$cells with angioblastic (EPC) activity. The authors reported that although $2 \%$ of mobilized human peripheral blood $\mathrm{CD} 34^{+}$cells 
coexpressed KDR and CD133, mature CD34 ${ }^{+-}$ $\mathrm{KDR}^{+}$human umbilical vein endothelial cells (chosen as representative of a mature vascular endothelial population) failed to express $\mathrm{CD} 133$, and thus the circulating $\mathrm{CD} 34^{+} \mathrm{KDR}^{+-}$ $\mathrm{CD}_{133^{+}}$cells were thought to represent a progenitor cell phenotype. To confirm the presence of CD133 and KDR expressing cells in vivo, Peichev et al. examined the luminal surfaces of implanted left ventricular assist devices in human subjects with heart failure and identified some surface adhering cells expressing CD133 and KDR. Based on this evidence, the investigators concluded that a human EPC could be defined as a circulating $\mathrm{CD} 34^{+}$cell that coexpresses CD133 and KDR. Subsequently, this pattern of cell surface antigen expression has been one of the most popular to use when attempting to identify circulating EPC in human subjects. Nonetheless, no direct evidence was presented in the original manuscript that isolated and purified human circulating $\mathrm{CD}_{34}{ }^{+} \mathrm{KDR}^{+} \mathrm{CD} 33^{+}$cells directly participate in generating the endothelial lining of the implanted left ventricular device or whether the cells attached to the device were hematopoietic or endothelial in origin. Because these antigens are all known to be expressed by hematopoietic stem and early progenitor cells, one would have liked to see the comparative enrichments of the putative EPCs compared to the potentially contaminating hematopoietic subsets that may have been present.

Although CD34, CD133, and/or KDR expression have been used to identify human circulating EPCs in thousands of papers since 2000, and many of the papers have reported statistically significant correlations between the blood concentration of the selected putative EPC subset and a disease state, few have attempted to formally compare the functional properties of isolated human circulating $\mathrm{CD} 4^{+} \mathrm{KDR}^{+} \mathrm{CD} 133^{+}$cells in hematopoietic and endothelial assays (reviewed in Alaiti et al. 2010). In one instance, Case et al. (2007) reported that purified $\mathrm{CD} 34^{+} \mathrm{KDR}^{+} \mathrm{CD} 133^{+}$ cells were highly enriched in hematopoietic progenitor activity but did not give rise to any endothelial colonies in vitro. Perhaps not surprising given all the rationale in the above studies, more than $99 \%$ of the hematopoietic progenitor $\mathrm{CD}_{3} 4^{+} \mathrm{KDR}^{+} \mathrm{CD}_{133^{+}}$cells coexpressed CD45, the common leukocyte antigen (this antigen is not expressed in endothelial cells even at the mRNA level). Timmermans et al. (2007) have also reported that colonies of endothelial cells that display high proliferative potential are derived only from a human cord blood or bone marrow $\mathrm{CD} 34^{+} \mathrm{CD} 45^{-}$population of cells and not from $\mathrm{CD} 34^{+} \mathrm{CD} 45^{+}$cells (which were enriched for hematopoietic colony forming cells). Thus, several labs have independently determined that the putative EPCs expressing CD34, CD133, and KDR that express the CD45 antigen are hematopoietic cells with colony forming activity and fail to give rise to endothelial cells during in vitro culture or directly form blood vessels in vitro or in vivo (Fig. 2).

The question of whether a cell expressing CD45 from adult human peripheral blood could represent an EPC has been controversial for some time and some of this controversy can be attributable to the underlying assumptions of the flow cytometric approaches used. Significant changes have occurred in both the hardware and software used in flow cytometry rate event analysis over the past decade (Herzenberg et al. 2006; Parks et al. 2006; Duda et al. 2007a). Newer digital machines with advanced resolution and data storage capabilities permit the identification of up to 20 distinct cellular parameters (Perfetto et al. 2006). Inherent in the ability to discriminate such a plethora of biologic data are improvements in the analytical software that are required to reduce spectral overlap by applying softwaregenerated postacquisition compensation (based on compensation bead controls) and the use of bi-exponential scaling to properly visualize events below and above the zero axis (De Rosa and Roederer 2001; Parks et al. 2006). These advances, termed polychromatic flow cytometry (PFC), have permitted discovery of novel rare cell subsets, further characterized the functionality of established cell populations, and even discovered gross errors in phenotyping cells when compared to conventional flow cytometry practices (reviewed in Abdul-Salam et al. 2005; 
M.C. Yoder
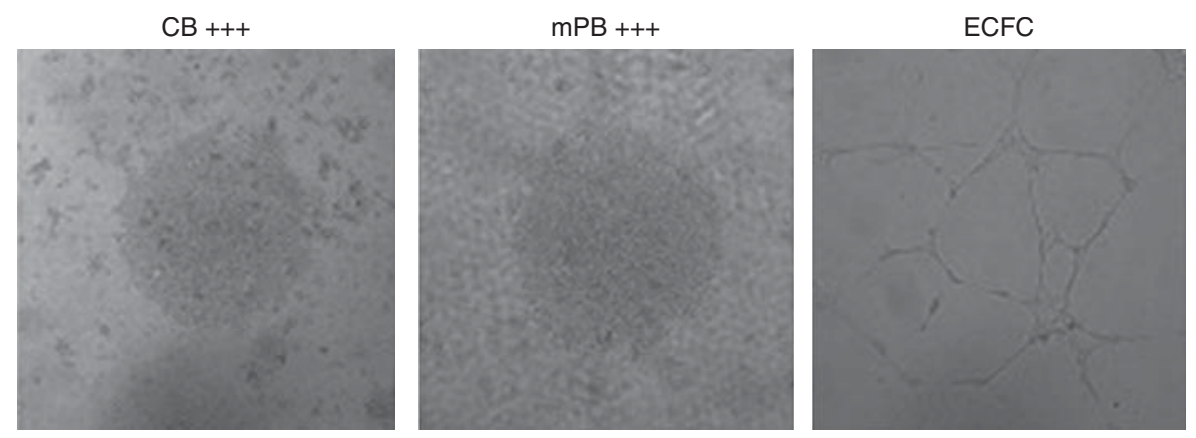

Figure 2. Formation of capillary-like structures in Matrigel coated plates. Photomicrographs $(20 \times$ magnification) of freshly sorted cord blood (CB) - or mobilized peripheral blood (mPB)-derived $\mathrm{CD}_{34} 4^{+} \mathrm{AC} 133^{+}$ VEGFR2 ${ }^{+}$cells and early passage endothelial colony-forming cells (ECFCs) plated over Matrigel. The triple positive $\mathrm{CB}$ - and $\mathrm{mPB}$-derived cells failed to form capillary-like structures, whereas the ECFC formed numerous lumenized structures. (Figure adapted from Case 2007; reprinted, with permission, from Elsevier (C) 2007.)

Herzenberg et al. 2006; Parks et al. 2006; Tung et al. 2007). Although numerous publications have proposed methods for resolution of circulating EPCs from circulating endothelial cells or other blood cell elements (Asahara et al. 1997; Gehling et al. 2000; Mancuso et al. 2001, 2009; Bertolini et al. 2003, 2006; Willett et al. 2004, 2005; Abdul-Salam et al. 2005; Khan et al. 2005; Goon et al. 2006; Duda et al. 2007b; Van Craenenbroeck et al. 2008; Widemann et al. 2008), several recent publications have applied PFC to the identification of putative EPCs and have resolved the subsets into proangiogenic hematopoietic cells (Fig. 3) and circulating endothelial colony-forming cells (Estes et al. 2010a,b; Schmidt-Lucke et al. 2010). Despite the use of advanced PFC techniques, to demonstrate that nearly all $\mathrm{CD} 133^{+} \mathrm{CD} 34^{+} \mathrm{KDR}^{+}$cells are $\mathrm{CD}_{4} 5^{+}$and thus by definition hematopoietic, the field will only become clarified on identification of novel cell surface molecules that unambiguously identify the EPCs (see below for proposed definition of an EPC).

The final method to identify a human circulating EPC is based on colony forming ability of the plated MNC in vitro. The original description of cluster-forming cells appearing within 5 days of plating $\mathrm{CD} 34^{+}$cells as a putative EPC characteristic (Asahara et al. 1997) was expanded on by Ito and colleagues who also isolated and plated blood cells on fibronectin- coated dishes (Ito et al. 1999). One day later the nonadherent cells were removed and replated onto fibronectin-coated dishes, and the number of clusters that emerged at 7 days of replating was used to indicate the number of putative EPCs. The rationale for preplating the MNC for $24 \mathrm{~h}$ was to remove any monocytes, macrophages, or circulating mature endothelial cells in the MNC fraction that could contaminate the putative EPC assay system. Although laudable in intent, the failure to show that all hematopoietic or endothelial elements were depleted by the preplating step diminished the impact of the improved methodology. Hill et al. (2003) further modified the EPC cluster assay, by preplating blood cells for $48 \mathrm{~h}$, then replating the nonadherent cells to quantify the emergence of the EPC-derived colonies. This assay has been commercialized and the putative EPC (that produce the progeny that form the colony) have been referred to as colony forming unit-Hill (CFU-Hill; Fig. 1). The CFU-Hill assay has been used to demonstrate a significant inverse correlation between the circulating CFU-Hill concentration and Framingham cardiovascular risk score in human subjects (Hill et al. 2003). Subsequent transcriptome, proteomic, and functional analyses have determined that CFU-Hill are more closely related to human hematopoietic cells than to primary endothelial cells. 

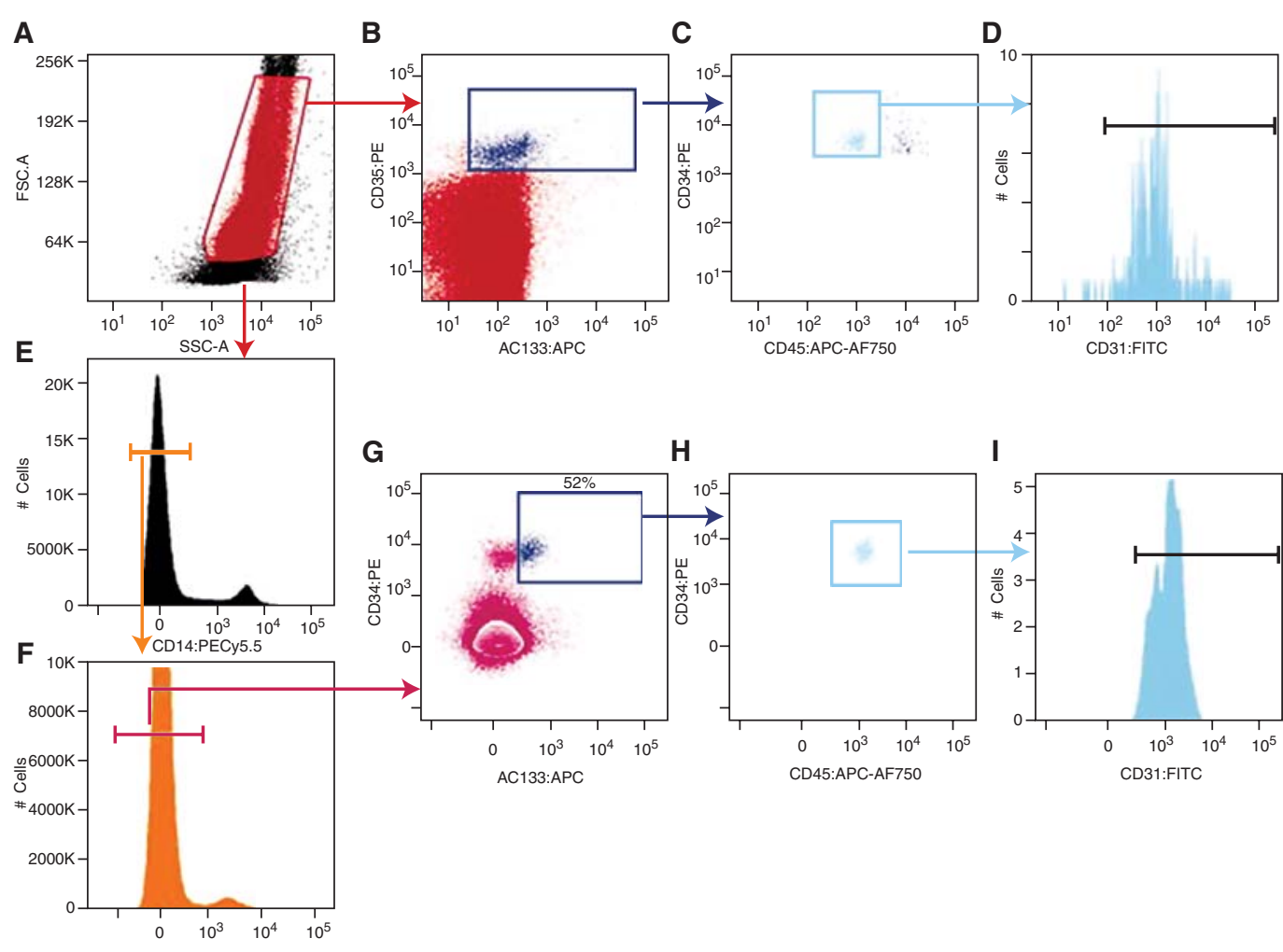

Figure 3. Frequency analysis of $\mathrm{CD} 31^{+} \mathrm{CD} 34^{\text {bright }} \mathrm{CD} 45^{\mathrm{dim}} \mathrm{AC} 133^{+}$cells using two distinct methods of analysis. In the first strategy $(A-D)$, manually compensated data collected on a digital flow cytometer were visualized on plots with logarithmic scaling. Mononuclear cells (MNCs) (red gate in $A$ ) were identified on a forward and side scatter (FSC/SSC) plot and subgated onto a bivariant antigen plot to identify CD $34^{\text {bright }}{ }^{\mathrm{AC}} 133^{+}$cells (dark blue gate in $B$ ). $\mathrm{CD} 34^{\text {bright }} \mathrm{AC} 133^{+}$cells were further gated to identify the $\mathrm{CD} 45^{\mathrm{dim}}$ subpopulation (light blue gate in $C)$. $\mathrm{CD} 31$ expression on the resulting $\mathrm{CD} 34^{\text {bright }} \mathrm{AC} 133^{+} \mathrm{CD} 45^{\mathrm{dim}}$ cells was confirmed on a CD31 histogram $(D)$. In this first strategy $(A-D)$, gate boundaries were set using Boolean gating and negative isotype controls. In the second strategy $(E-I)$, uncompensated data was collected on a digital flow cytometer, compensated after acquisition by using software, and visualized in plots with biexponential scaling (linear and logarithmic). MNCs (red gate in $A$ ) were identified on a FSC/SSC plot and then CD14 ${ }^{-}$cells (orange gate in $E$ ) were identified. All $\mathrm{CD}_{14}{ }^{-}$events were then assessed for viability (ViViD) and glycophorin A (GlyA) (F). The CD14 ${ }^{-} \mathrm{GlyA}^{-}$ $\mathrm{ViViD}^{-}$(pink gate in $F$ ) were subgated onto a bivariant antigen plot to identify $\mathrm{CD}_{14}^{-} \mathrm{GlyA}^{-} \mathrm{ViViD}^{-}$ $\mathrm{CD} 34^{\text {bright }} \mathrm{AC} 33^{+}$cells (dark blue gate in $\mathrm{G}$ ). $\mathrm{CD}^{-} 4^{-} \mathrm{GlyA}^{-} \mathrm{ViViD}^{-} \mathrm{CD} 34^{\text {bright }} \mathrm{AC} 33^{+}$cells were further subgated to identify the CD45 ${ }^{\mathrm{dim}}$ subpopulation (light blue gate in $H$ ). CD31 expression was confirmed on a CD31 histogram. In the second approach $(E-I)$, fluorescence minus one gating controls were used to set gate boundaries. (Figure adapted from Estes et al. 2010; reprinted, with permission, from John Wiley \& Sons (C) 2010.)

Another assay system identifies outgrowth endothelial cells (OECs) possessing clonal endothelial colony-forming cell (ECFC) ability within 1-3 wk of culture, when blood cells are plated on matrix coated dishes with added growth factors (Gulati et al. 2003, 2004; Bompais et al. 2004; Hur et al. 2004; Ingram et al.
2004, 2005; Yoon et al. 2005; Guven et al. 2006; Shepherd et al. 2006; Melero-Martin et al. 2007; Nagano et al. 2007; Timmermans et al. 2007; Au et al. 2008). A hierarchy of clonal proliferative potential is displayed by the ECFC with some colonies growing to more than 10,000 progeny from a single cell plated 14 
M.C. Yoder

days earlier (Ingram et al. 2004, 2005). The cord blood ECFC display high telomerase activity and vigorous in vivo human vessel formation when suspended in a matrix and implanted into immunodeficient mice (Ingram et al. 2004). The ability of these ECFCs to display spontaneous vasculogenic properties, to integrate long-term into the systemic vasculature of the host animal, and to remodel into arteries and veins in vivo distinguishes this EPC from all other types of cells that have been given this term (Bompais et al. 2004; Gulati et al. 2004; Hur et al. 2004; Ingram et al. 2004, 2005; Yoon et al. 2005; Guven et al. 2006; Shepherd et al. 2006; Melero-Martin et al. 2007; Nagano et al. 2007; Timmermans et al. 2007; Au et al. 2008).

Although the general consensus purports that endothelial cell turnover in systemic blood vessels is low in adult subjects, ample evidence has also been presented to suggest that the endothelium in some blood vessels is easily detectable (Wright 1968, 1971, 1972; Caplan and Schwartz 1973; Schwartz and Benditt 1976; Kunz et al. 1978; Taylor and Lewis 1986). In fact, in young experimental animals, endothelial replication rates have been reported as high as $60 \%$ in certain focal areas within the aorta. Experimental injury to the aortic endothelium (direct denudation) or disorders such as hypertension, hyperlipidemia, and endotoxemia all lead to an increase in endothelial replication in rodent models (Wright 1968, 1971, 1972; Caplan and Schwartz 1973; Schwartz and Benditt 1976; Kunz et al. 1978; Taylor and Lewis 1986). Most evidence suggests that the proliferating cells are retained in the endothelial intimal layer; however, some circulating endothelial cells thought to be sloughed from the vascular endothelium may also possess proliferative potential. Because human adult aorta and cord blood artery and vein endothelial cells have been determined to possess the clonal hierarchical proliferative potential similar to the circulating ECFCs derived from cord blood and adult peripheral blood (Ingram et al. 2005), it is plausible that the circulating ECFCs may be derived from vascular endothelium. Only further study will permit a detailed clarification of the relationship between resident and circulating ECFCs.

\section{ROLE OF EPCs IN VARIOUS HUMAN CLINICAL DISORDERS}

A summary of the role of EPCs in human disease is complicated by the fact that so many different EPC definitions have been used. In many instances, circulating EPC concentrations have been enumerated and correlated to a disease state in an effort to serve as a biomarker for disease detection or staging (Alaiti et al. 2010). In some cases, the functional role of the EPCs has been elucidated when the cells were infused as a reparative therapy (Loomans et al. 2004). Defects in EPC function have also been identified in some patients with diabetes and potential therapies to restore certain aspects of EPC function have been proposed (Fadini et al. 2007). Despite the ambiguity in fully characterizing an EPC, numerous clinical trials have been conducted in patients with heart disease, diabetes, peripheral arterial disease, pulmonary disease, and cancer in which putative EPCs have been examined as a biomarker or used as a cell therapy to treat human subjects (see www.clinicaltrials.gov).

\section{DEFINING A HUMAN EPC}

A growing consensus is emerging that there are many circulating blood cells that participate in the process of new blood vessel formation and vascular repair. Controversy persists as to whether cells that display numerous features of the hematopoietic lineage but participate in new blood vessel formation should be called an EPC or not. If the term EPC is reserved for a progenitor cell for the endothelial lineage, we would propose that there are fundamental properties that this cell should display: a circulating cell that gives rise to progeny displaying clonal proliferative potential and differentiation restricted to the endothelial lineage, ability to form lumenized capillary-like tubes in vitro (cells must display cytoplasmic vacuolation capacity), and ability to form stable human blood vessels (cells must secrete a basement 
membrane) when implanted into tissues (with or without a scaffold) that become an integrated part of the host circulatory system and display potential to undergo remodeling to form the intima of arterial, venous, and capillary structures. At present, the rare circulating ECFCs display these features while most other bone marrow-derived cells currently called EPCs fail to do so (Hirschi et al. 2008). Finding a unique cell surface marker that would permit prospective isolation and enrichment of cells displaying the above activities would certainly clarify the EPC identity and must remain a focus for the field.

\section{ACKNOWLEDGMENTS}

We would like to thank Tiffany Lewallen for her expert administrative assistance in preparation of the article. This work was supported in part by funds from the Riley Children's Foundation. The author has no competing financial interests to disclose.

\section{REFERENCES}

Abdul-Salam F, Mansour MH, Al-Shemary T. 2005. The selective expression of distinct fucosylated glycoproteins on murine T and B lymphocyte subsets. Immunobiology 210: 695-708.

Adamo L, Naveiras O, Wenzel PL, McKinney-Freeman S, Mack PJ, Gracia-Sancho J, Suchy-Dicey A, Yoshimoto M, Lensch MW, Yoder MC, et al. 2009. Biomechanical forces promote embryonic haematopoiesis. Nature 459: $1131-1135$.

Aird WC. 2007. Introductory essay: The endothelium in health and disease. In Endothelial biomedicine (ed. Aird WC), pp. 1111-1112. Cambridge University Press, New York.

Alaiti MA, Ishikawa M, Costa MA. 2010. Bone marrow and circulating stem/progenitor cells for regenerative cardiovascular therapy. Transl Res 156: 112-129.

Asahara T, Murohara T, Sullivan A, Silver M, van der Zee R, Li T, Witzenbichler B, Schatteman G, Isner JM. 1997. Isolation of putative progenitor endothelial cells for angiogenesis. Science 275: 964-967.

Au P, Daheron LM, Duda DG, Cohen KS, Tyrrell JA, Lanning RM, Fukumura D, Scadden DT, Jain RK. 2008. Differential in vivo potential of endothelial progenitor cells from human umbilical cord blood and adult peripheral blood to form functional long-lasting vessels. Blood 111: $1302-1305$.

Bautch VL. 2010. Cancer: Tumour stem cells switch sides. Nature 468: 770-771.
Berger K, Sauvage LR, Rao AM, Wood SJ. 1972. Healing of arterial prostheses in man: Its incompleteness. Ann Surg 175: $118-127$.

Bertolini F, Paul S, Mancuso P, Monestiroli S, Gobbi A, Shaked Y, Kerbel RS. 2003. Maximum tolerable dose and low-dose metronomic chemotherapy have opposite effects on the mobilization and viability of circulating endothelial progenitor cells. Cancer Res 63: 4342-4346.

Bertolini F, Shaked Y, Mancuso P, Kerbel RS. 2006. The multifaceted circulating endothelial cell in cancer: Towards marker and target identification. Nat Rev Cancer 6: 835-845.

Bompais H, Chagraoui J, Canron X, Crisan M, Liu XH, Anjo A, Tolla-Le Port C, Leboeuf M, Charbord P, Bikfalvi A, et al. 2004. Human endothelial cells derived from circulating progenitors display specific functional properties compared with mature vessel wall endothelial cells. Blood 103: $2577-2584$

Caplan BA, Schwartz CJ. 1973. Increased endothelial cell turnover in areas of in vivo Evans Blue uptake in the pig aorta. Atherosclerosis 17: 401-417.

Case J, Mead LE, Bessler WK, Prater D, White HA, Saadatzadeh MR, Bhavsar JR, Yoder MC, Haneline LS, Ingram DA. 2007. Human $\mathrm{CD} 34^{+}$AC133 ${ }^{+}$VEGFR-2 $2^{+}$cells are not endothelial progenitor cells but distinct, primitive hematopoietic progenitors. Exp Hematol 35: 1109-1118.

Chen MJ, Yokomizo T, Zeigler BM, Dzierzak E, Speck NA. 2009. Runx1 is required for the endothelial to haematopoietic cell transition but not thereafter. Nature 457: 887-891.

Clowes AW, Gown AM, Hanson SR, Reidy MA. 1985. Mechanisms of arterial graft failure. 1. Role of cellular proliferation in early healing of PTFE prostheses. Am J Pathol 118: $43-54$.

Clowes AW, Kirkman TR, Clowes MM. 1986. Mechanisms of arterial graft failure. II. Chronic endothelial and smooth muscle cell proliferation in healing polytetrafluoroethylene prostheses. J Vasc Surg 3: 877-884.

Davis GE, Senger DR. 2008. Extracellular matrix mediates a molecular balance between vascular morphogenesis and regression. Curr Opin Hematol 15: 197-203.

De Rosa SC, Roederer M. 2001. Eleven-color flow cytometry. A powerful tool for elucidation of the complex immune system. Clin Lab Med 21: 697-712.

Duda DG, Cohen KS, Scadden DT, Jain RK. 2007a. A protocol for phenotypic detection and enumeration of circulating endothelial cells and circulating progenitor cells in human blood. Nat Protoc 2: 805-810.

Duda DG, Jain RK, Willett CG. 2007b. Antiangiogenics: the potential role of integrating this novel treatment modality with chemoradiation for solid cancers. J Clin Oncol 25: 4033-4042.

Eilken HM, Adams RH. 2010. Dynamics of endothelial cell behavior in sprouting angiogenesis. Curr Opin Cell Biol 22: $617-625$.

Eizawa T, Ikeda U, Murakami Y, Matsui K, Yoshioka T, Takahashi M, Muroi K, Shimada K. 2004. Decrease in circulating endothelial progenitor cells in patients with stable coronary artery disease. Heart 90: 685-686.

Estes ML, Mund JA, Ingram DA, Case J. 2010a. Identification of endothelial cells and progenitor cell subsets in 
M.C. Yoder

human peripheral blood. Curr Protoc Cytom (Chapter 9: Unit 9) 33: 31-11.

Estes ML, Mund JA, Mead LE, Prater DN, Cai S, Wang H, Pollok KE, Murphy MP, An CST, Srour EF, et al. 2010b. Application of polychromatic flow cytometry to identify novel subsets of circulating cells with angiogenic potential. Cytometry Part A 77: 831-839.

Fadini GP, de Kreutzenberg SV, Coracina A, Baesso I, Agostini C, Tiengo A, Avogaro A. 2006a. Circulating CD34 ${ }^{+}$ cells, metabolic syndrome, and cardiovascular risk. Eur Heart J 27: 2247-2255.

Fadini GP, Sartore S, Albiero M, Baesso I, Murphy E, Menegolo M, Grego F, Vigili de Kreutzenberg S, Tiengo A, Agostini C, et al. 2006b. Number and function of endothelial progenitor cells as a marker of severity for diabetic vasculopathy. Arterioscler Thromb Vasc Biol 26: 2140-2146.

Fadini GP, Pucci L, Vanacore R, Baesso I, Penno G, Balbarini A, Di Stefano R, Miccoli R, de Kreutzenberg S, Coracina A, et al. 2007. Glucose tolerance is negatively associated with circulating progenitor cell levels. Diabetologia 50: 2156-2163.

Ferkowicz MJ, Yoder MC. 2005. Blood island formation: Longstanding observations and modern interpretations. Exp Hematol 33: 1041-1047.

Ferkowicz MJ, Starr M, Xie X, Li W, Johnson SA, Shelley WC, Morrison PR, Yoder MC. 2003. CD41 expression defines the onset of primitive and definitive hematopoiesis in the murine embryo. Development 130: 4393-4403.

Florentin RA, Nam SC, Lee KT, Thomas WA. 1969. Increased $3 \mathrm{H}$-thymidine incorporation into endothelial cells of swine fed cholesterol for 3 days. Exp Mol Pathol 10: 250-255.

Gao D, Mittal V. 2009. The role of bone-marrow-derived cells in tumor growth, metastasis initiation and progression. Trends Mol Med 15: 333-343.

Gao D, Nolan DJ, Mellick AS, Bambino K, McDonnell K, Mittal V. 2008. Endothelial progenitor cells control the angiogenic switch in mouse lung metastasis. Science 319: 195-198.

Gehling UM, Ergun S, Schumacher U, Wagener C, Pantel K, Otte M, Schuch G, Schafhausen P, Mende T, Kilic N, et al. 2000. In vitro differentiation of endothelial cells from AC133-positive progenitor cells. Blood 95: 3106-3112.

Goon PK, Boos CJ, Stonelake PS, Blann AD, Lip GY. 2006. Detection and quantification of mature circulating endothelial cells using flow cytometry and immunomagnetic beads: A methodological comparison. Thromb Haemost 96: $45-52$

Gulati R, Jevremovic D, Peterson TE, Chatterjee S, Shah V, Vile RG, Simari RD. 2003. Diverse origin and function of cells with endothelial phenotype obtained from adult human blood. Circ Res 93: 1023-1025.

Gulati R, Jevremovic D, Witt TA, Kleppe LS, Vile RG, Lerman A, Simari RD. 2004. Modulation of the vascular response to injury by autologous blood-derived outgrowth endothelial cells. Am J Physiol Heart Circ Physiol 287: H512-517.

Guven H, Shepherd RM, Bach RG, Capoccia BJ, Link DC 2006. The number of endothelial progenitor cell colonies in the blood is increased in patients with angiographically significant coronary artery disease. J Am Coll Cardiol 48: 1579-1587.

Hassan NF, Campbell DE, Douglas SD. 1986. Purification of human monocytes on gelatin-coated surfaces. J Immunol Methods 95: 273-276.

Herring M, Baughman S, Glover J, Kesler K, Jesseph J, Campbell J, Dilley R, Evan A, Gardner A. 1984. Endothelial seeding of Dacron and polytetrafluoroethylene grafts: the cellular events of healing. Surgery 96: 745-755.

Herzenberg LA, Tung J, Moore WA, Parks DR. 2006. Interpreting flow cytometry data: a guide for the perplexed. Nat Immunol 7: 681-685.

Hill JM, Zalos G, Halcox JP, Schenke WH, Waclawiw MA, Quyyumi AA, Finkel T. 2003. Circulating endothelial progenitor cells, vascular function, and cardiovascular risk. N Engl J Med 348: 593-600.

Hirschi KK, Ingram DA, Yoder MC. 2008. Assessing identity, phenotype, and fate of endothelial progenitor cells. Arterioscler Thromb Vasc Biol 28: 1584-1595.

Hughes AD, Coady E, Raynor S, Mayet J, Wright AR, Shore AC, Kooner JS, Thom SA, Chaturvedi N. 2007. Reduced endothelial progenitor cells in European and South Asian men with atherosclerosis. Eur J Clin Invest 37: 35-41.

Hur J, Yoon CH, Kim HS, Choi JH, Kang HJ, Hwang KK, Oh BH, Lee MM, Park YB. 2004. Characterization of two types of endothelial progenitor cells and their different contributions to neovasculogenesis. Arterioscler Thromb Vasc Biol 24: 288-293.

Ingram DA, Mead LE, Tanaka H, Meade V, Fenoglio A, Mortell K, Pollok K, Ferkowicz MJ, Gilley D, Yoder MC. 2004. Identification of a novel hierarchy of endothelial progenitor cells using human peripheral and umbilical cord blood. Blood 104: 2752-2760.

Ingram DA, Mead LE, Moore DB, Woodard W, Fenoglio A, Yoder MC. 2005. Vessel wall-derived endothelial cells rapidly proliferate because they contain a complete hierarchy of endothelial progenitor cells. Blood 105: 2783-2786.

Iruela-Arispe ML, Davis GE. 2009. Cellular and molecular mechanisms of vascular lumen formation. Dev Cell 16: 222-231.

Ito H, Rovira II, Bloom ML, Takeda K, Ferrans VJ, Quyyumi AA, Finkel T. 1999. Endothelial progenitor cells as putative targets for angiostatin. Cancer Res 59: 5875-5877.

Khan SS, Solomon MA, McCoy JP Jr. 2005. Detection of circulating endothelial cells and endothelial progenitor cells by flow cytometry. Cytometry B Clin Cytom 64: 1-8.

Kunz J, Schreiter B, Schubert B, Voss K, Krieg K. 1978. Experimental investigations on the regeneration of aortic endothelial cells. Automatic and visual evaluation of autoradiograms (author's transl). Acta Histochem 61: $53-63$.

Kunz GA, Liang G, Cuculi F, Gregg D, Vata KC, Shaw LK, Goldschmidt-Clermont PJ, Dong C, Taylor DA, Peterson ED. 2006. Circulating endothelial progenitor cells predict coronary artery disease severity. Am Heart J 152: 190-195.

Loomans CJ, de Koning EJ, Staal FJ, Rookmaaker MB, Verseyden C, de Boer HC, Verhaar MC, Braam B, Rabelink TJ, van Zonneveld AJ. 2004. Endothelial progenitor cell dysfunction: A novel concept in the pathogenesis of 
vascular complications of type 1 diabetes. Diabetes 53: 195-199.

Lyden D, Hattori K, Dias S, Costa C, Blaikie P, Butros L, Chadburn A, Heissig B, Marks W, Witte L, et al. 2001. Impaired recruitment of bone-marrow-derived endothelial and hematopoietic precursor cells blocks tumor angiogenesis and growth. Nat Med 7: 1194-1201.

Malczak HT, Buck RC. 1977. Regeneration of endothelium in rat aorta after local freezing. A scanning electron microscopic study. Am J Pathol 86: 133-148.

Mancuso P, Bertolini F. 2010. Circulating endothelial cells as biomarkers in clinical oncology. Microvasc Res 79: 224-228.

Mancuso P, Burlini A, Pruneri G, Goldhirsch A, Martinelli G, Bertolini F. 2001. Resting and activated endothelial cells are increased in the peripheral blood of cancer patients. Blood 97: 3658-3661.

Mancuso P, Colleoni M, Calleri A, Orlando L, Maisonneuve P, Pruneri G, Agliano A, Goldhirsch A, Shaked Y, Kerbel RS, et al. 2006. Circulating endothelial-cell kinetics and viability predict survival in breast cancer patients receiving metronomic chemotherapy. Blood 108: 452-459.

Mancuso P, Antoniotti P, Quarna J, Calleri A, Rabascio C, Tacchetti C, Braidotti P, Wu HK, Zurita AJ, Saronni L, et al. 2009. Validation of a standardized method for enumerating circulating endothelial cells and progenitors: Flow cytometry and molecular and ultrastructural analyses. Clin Cancer Res 15: 267-273.

Manderson JA, Campbell GR. 1986. Venous response to endothelial denudation. Pathology 18: 77-87.

Medina RJ, O’Neill CL, Sweeney M, Guduric-Fuchs J, Gardiner TA, Simpson DA, Stitt AW. 2010. Molecular analysis of endothelial progenitor cell (EPC) subtypes reveals two distinct cell populations with different identities. BMC Med Genomics 3: 18.

Melero-Martin JM, Khan ZA, Picard A, Wu X, Paruchuri S, Bischoff J. 2007. In vivo vasculogenic potential of human blood-derived endothelial progenitor cells. Blood 109: 4761-4768.

Nagano M, Yamashita T, Hamada H, Ohneda K, Kimura K, Nakagawa T, Shibuya M, Yoshikawa H, Ohneda O. 2007. Identification of functional endothelial progenitor cells suitable for the treatment of ischemic tissue using human umbilical cord blood. Blood 110: 151-160.

Nolan DJ, Ciarrocchi A, Mellick AS, Jaggi JS, Bambino K, Gupta S, Heikamp E, McDevitt MR, Scheinberg DA, Benezra R, et al. 2007. Bone marrow-derived endothelial progenitor cells are a major determinant of nascent tumor neovascularization. Genes Dev 21: 1546-1558.

Parks DR, Roederer M, Moore WA. 2006. A new "Logicle" display method avoids deceptive effects of logarithmic scaling for low signals and compensated data. Cytometry A 69: 541-551.

Peichev M, Naiyer AJ, Pereira D, Zhu Z, Lane WJ, Williams M, Oz MC, Hicklin DJ, Witte L, Moore MA, et al. 2000. Expression of VEGFR-2 and AC133 by circulating human $\mathrm{CD} 34^{+}$cells identifies a population of functional endothelial precursors. Blood 95: 952-958.

Perfetto SP, Ambrozak D, Nguyen R, Chattopadhyay P, Roederer M. 2006. Quality assurance for polychromatic flow cytometry. Nat Protoc 1: 1522-1530.
Pitulescu ME, Adams RH. 2010. Eph/ephrin moleculesA hub for signaling and endocytosis. Genes Dev 24: 2480-2492.

Prescott MF, Muller KR. 1983. Endothelial regeneration in hypertensive and genetically hypercholesterolemic rats. Arteriosclerosis 3: 206-214.

Prokopi M, Pula G, Mayr U, Devue C, Gallagher J, Xiao Q, Boulanger CM, Westwood N, Urbich C, Willeit J, et al. 2009. Proteomic analysis reveals presence of platelet microparticles in endothelial progenitor cell cultures. Blood 114: 723-732.

Rafii S, Oz MC, Seldomridge JA, Ferris B, Asch AS, Nachman RL, Shapiro F, Rose EA, Levin HR. 1995. Characterization of hematopoietic cells arising on the textured surface of left ventricular assist devices. Ann Thorac Surg 60: 1627-1632.

Ricci-Vitiani L, Pallini R, Biffoni M, Todaro M, Invernici G, Cenci T, Maira G, Parati EA, Stassi G, Larocca LM, et al. 2010. Tumour vascularization via endothelial differentiation of glioblastoma stem-like cells. Nature 468: $824-828$.

Risau W, Flamme I. 1995. Vasculogenesis. Annu Rev Cell Dev Biol 11: 73-91.

Sabin FR. 2002. Preliminary note on the differentiation of angioblasts and the method by which they produce blood-vessels, blood-plasma and red blood-cells as seen in the living chick. 1917. J Hematother Stem Cell Res 11: $5-7$.

Schmeisser A, Garlichs CD, Zhang H, Eskafi S, Graffy C, Ludwig J, Strasser RH, Daniel WG. 2001. Monocytes coexpress endothelial and macrophagocytic lineage markers and form cord-like structures in Matrigel under angiogenic conditions. Cardiovasc Res 49: 671-680.

Schmeisser A, Graffy C, Daniel WG, Strasser RH. 2003. Phenotypic overlap between monocytes and vascular endothelial cells. Adv Exp Med Biol 522: 59-74.

Schmidt-Lucke C, Rossig L, Fichtlscherer S, Vasa M, Britten M, Kamper U, Dimmeler S, Zeiher AM. 2005. Reduced number of circulating endothelial progenitor cells predicts future cardiovascular events: Proof of concept for the clinical importance of endogenous vascular repair. Circulation 111: 2981-2987.

Schmidt-Lucke C, Fichtlscherer S, Aicher A, Tschope C, Schultheiss HP, Zeiher AM, Dimmeler S. 2010. Quantification of circulating endothelial progenitor cells using the modified ISHAGE protocol. PLoS One 5: e13790.

Schwartz SM, Benditt EP. 1976. Clustering of replicating cells in aortic endothelium. Proc Natl Acad Sci 73: 651-653.

Schwartz SM, Benditt EP. 1977. Aortic endothelial cell replication. I. Effects of age and hypertension in the rat. Circ Res 41: 248-255.

Schwartz SM, Stemerman MB, Benditt EP. 1975. The aortic intima. II. Repair of the aortic lining after mechanical denudation. Am J Pathol 81: 15-42.

Schwartz SM, Gajdusek CM, Reidy MA, Selden SC 3rd, Haudenschild CC. 1980. Maintenance of integrity in aortic endothelium. Fed Proc 39: 2618-2625.

Schwartz SM, Gajdusek CM, Selden SC 3rd. 1981. Vascular wall growth control: the role of the endothelium. Arteriosclerosis 1: 107-126. 
M.C. Yoder

Seandel M, Butler J, Lyden D, Rafii S. 2008. A catalytic role for proangiogenic marrow-derived cells in tumor neovascularization. Cancer Cell 13: 181-183.

Shaked Y, Ciarrocchi A, Franco M, Lee CR, Man S, Cheung AM, Hicklin DJ, Chaplin D, Foster FS, Benezra R, et al. 2006. Therapy-induced acute recruitment of circulating endothelial progenitor cells to tumors. Science 313: 1785-1787.

Shepherd BR, Enis DR, Wang F, Suarez Y, Pober JS, Schechner JS. 2006. Vascularization and engraftment of a human skin substitute using circulating progenitor cell-derived endothelial cells. FASEB J 20: 1739-1741.

Taylor RG, Lewis JC. 1986. Endothelial cell proliferation and monocyte adhesion to atherosclerotic lesions of white carneau pigeons. Am J Pathol 125: 152-160.

Tepper OM, Galiano RD, Capla JM, Kalka C, Gagne PJ, Jacobowitz GR, Levine JP, Gurtner GC. 2002. Human endothelial progenitor cells from type II diabetics exhibit impaired proliferation, adhesion, and incorporation into vascular structures. Circulation 106: 2781-2786.

Timmermans F, Van Hauwermeiren F, De Smedt M, Raedt R, Plasschaert F, De Buyzere ML, Gillebert TC, Plum J, Vandekerckhove B. 2007. Endothelial outgrowth cells are not derived from $\mathrm{CD} 133^{+}$cells or $\mathrm{CD} 45^{+}$hematopoietic precursors. Arterioscler Thromb Vasc Biol 27: 1572-1579.

Tongers J, Roncalli JG, Losordo DW. 2010. Role of endothelial progenitor cells during ischemia-induced vasculogenesis and collateral formation. Microvasc Res 79: 200-206.

Tung JW, Heydari K, Tirouvanziam R, Sahaf B, Parks DR, Herzenberg LA. 2007. Modern flow cytometry: A practical approach. Clin Lab Med 27: 453-468.

Ueno H, Weissman IL. 2010. The origin and fate of yolk sac hematopoiesis: Application of chimera analyses to developmental studies. Int J Dev Biol 54: 1019-1031.

Van Craenenbroeck EM, Conraads VM, Van Bockstaele DR, Haine SE, Vermeulen K, Van Tendeloo VF, Vrints CJ, Hoymans VY. 2008. Quantification of circulating endothelial progenitor cells: A methodological comparison of six flow cytometric approaches. J Immunol Methods 332: $31-40$.

Wang R, Chadalavada K, Wilshire J, Kowalik U, Hovinga KE, Geber A, Fligelman B, Leversha M, Brennan C, Tabar V. 2010. Glioblastoma stem-like cells give rise to tumour endothelium. Nature 468: 829-833.

Werner N, Kosiol S, Schiegl T, Ahlers P, Walenta K, Link A, Bohm M, Nickenig G. 2005. Circulating endothelial progenitor cells and cardiovascular outcomes. $N$ Engl J Med 353: 999-1007.

Widemann A, Sabatier F, Arnaud L, Bonello L, Al-Massarani G, Paganelli F, Poncelet P, Dignat-George F. 2008. CD146-based immunomagnetic enrichment followed by multiparameter flow cytometry: A new approach to counting circulating endothelial cells. J Thromb Haemost 6: 869-876.

Willett CG, Boucher Y, di Tomaso E, Duda DG, Munn LL, Tong RT, Chung DC, Sahani DV, Kalva SP, Kozin SV, et al. 2004. Direct evidence that the VEGF-specific antibody bevacizumab has antivascular effects in human rectal cancer. Nat Med 10: 145-147.

Willett CG, Boucher Y, Duda DG, di Tomaso E, Munn LL, Tong RT, Kozin SV, Petit L, Jain RK, Chung DC, et al. 2005. Surrogate markers for antiangiogenic therapy and dose-limiting toxicities for bevacizumab with radiation and chemotherapy: Continued experience of a phase I trial in rectal cancer patients. JClin Oncol 23: 8136-8139.

Wright HP. 1968. Endothelial mitosis around aortic branches in normal guinea pigs. Nature 220: 78-79.

Wright HP. 1971. Areas of mitosis in aortic endothelium of guinea-pigs. J Pathol 105: 65-67.

Wright HP. 1972. Mitosis patterns in aortic endothelium. Atherosclerosis 15: 93-100.

Yoder MC, Mead LE, Prater D, Krier TR, Mroueh KN, Li F, Krasich R, Temm CJ, Prchal JT, Ingram DA. 2007. Redefining endothelial progenitor cells via clonal analysis and hematopoietic stem/progenitor cell principals. Blood 109: 1801-1809.

Yoon CH, Hur J, Park KW, Kim JH, Lee CS, Oh IY, Kim TY, Cho HJ, Kang HJ, Chae IH, et al. 2005. Synergistic neovascularization by mixed transplantation of early endothelial progenitor cells and late outgrowth endothelial cells: The role of angiogenic cytokines and matrix metalloproteinases. Circulation 112: 1618-1627.

Zilla P, Preiss P, Groscurth P, Rosemeier F, Deutsch M, Odell J, Heidinger C, Fasol R, von Oppell U. 1994. In vitro-lined endothelium: Initial integrity and ultrastructural events. Surgery 116: 524-534.

Zilla P, Bezuidenhout D, Human P. 2007. Prosthetic vascular grafts: Wrong models, wrong questions and no healing. Biomaterials 28: 5009-5027.

Zovein AC, Hofmann JJ, Lynch M, French WJ, Turlo KA, Yang Y, Becker MS, Zanetta L, Dejana E, Gasson JC, et al. 2008. Fate tracing reveals the endothelial origin of hematopoietic stem cells. Cell Stem Cell 3: 625-636. 


\title{
$\&_{\mathrm{CSH}}^{\infty} \&$ Cold Spring Harbor

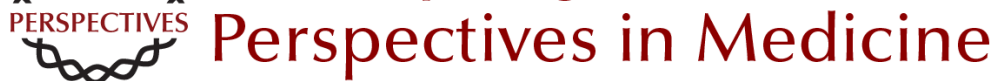

\section{Human Endothelial Progenitor Cells}

\author{
Mervin C. Yoder
}

Cold Spring Harb Perspect Med 2012; doi: 10.1101/cshperspect.a006692 originally published online September 28, 2011

\section{Subject Collection Angiogenesis}

Extracellular Matrix Regulation of Vascular Morphogenesis, Maturation, and Stabilization George E. Davis and Scott S. Kemp

Endothelial Cell-Pericyte Interactions in the Pathogenesis of Cerebral Cavernous Malformations (CCMs) Wang Min and Jenny Huanjiao Zhou

Lymphatic Clearance and Pump Function Jerome W. Breslin

Platelets and (Lymph)angiogenesis Harvey G. Roweth and Elisabeth M. Battinelli

Modeling Brain Vasculature Immune Interactions In Vitro Ruth Lyck, Hideaki Nishihara, Sidar Aydin, et al.

Human Endothelial Colony-Forming Cells Juan M. Melero-Martin

\section{The Beauty and Complexity of Blood Vessel} Patterning

Victoria L. Bautch and Yoh-suke Mukouyama

Endothelialitis, Microischemia, and

Intussusceptive Angiogenesis in COVID-19 Steven J. Mentzer, Maximilian Ackermann and Danny Jonigk
Regulation of the Blood-Brain Barrier in Health and Disease Cara C. Rada, Kanako Yuki, Jie Ding, et al.

Targeting Angiogenesis via Resolution of Inflammation

Abigail G. Kelly and Dipak Panigrahy

Notch Signaling in the Vasculature: Angiogenesis and Angiocrine Functions

Sana S. Hasan and Andreas Fischer

Signal Transduction and Gene Regulation in the Endothelium

Michel V. Levesque and Timothy Hla

Buttons and Zippers: Endothelial Junctions in

Lymphatic Vessels

Peter Baluk and Donald M. McDonald

Endothelial Cell Fate Determination: A Top Notch Job in Vascular Decision-Making

L.A. Naiche, Stephanie R. Villa and Jan K. Kitajewski

Leukocyte Trafficking in Lymphatic Vessels Aline Bauer, Hazal Tatliadim and Cornelia Halin

Lymphatic Tissue and Organ Engineering for In Vitro Modeling and In Vivo Regeneration Anna M. Kolarzyk, Gigi Wong and Esak Lee

For additional articles in this collection, see http://perspectivesinmedicine.cshlp.org/cgi/collection/ 